\title{
STUDENTS' ANALYSES TOWARD GRAMMATICAL ERRORS ON SOCIAL MEDIA'S POSTS: CASE STUDY IN POLITEKNIK NEGERI MEDAN
}

\author{
Orli Binta Tumanggor ${ }^{*}$, Aprilza Aswani ${ }^{2}$, Winda Syafitri ${ }^{3}$ \\ 1,2,3 Politeknik Negeri Medan, Indonesia \\ orlitumanggor@polmed.ac.id
}

\begin{abstract}
Learning a second or foreign language is quite different from acquiring the first language or mother tongue. There are some differences found in different languages including the grammatical pattern. It tends to make the learners have errors in writing or speaking English. This study investigated the students' analyses toward grammatical error on social media posts. The subject of research is 15 students of Politeknik Negeri Medan majoring in computer engineering. There were 20 errors found by students which were further analyzed by using surface taxonomy theory. This study showed that the students' analyses were dominantly on misformation analysis, followed by omission, addition, and misordering analysis. Misformation is the highest rate of errors found as it actually covers many grammar topics in English such as tenses, participle, verbal sentence, nominal sentence, part of speech, and others as analyzed by students on social media posts. Besides, no students found blends analysis, it might due to their lack of knowledge of blends themselves.
\end{abstract}

Keyword: Grammatical errors, Social Media, Surface Taxonomy Theory

\section{INTRODUCTION}

English as a foreign language in Indonesia is studied in all levels of education including in undergraduate school. Acquiring a language as a second or a foreign one is quite different from acquiring the first language and mother tongue (Iksan \& Duriani, 2015). There are some differences found in different languages including the grammatical pattern. Grammar has been a center of studying language which cannot be separated from those four language proficiencies namely speaking and writing as productive skills and listening and reading as receptive skills.

Grammar is a set of rules that explores the forms and structures of sentences that can be used in a language (Gleason, J. B. \& Ratner, 2016; Thornbury, 1999). There are two important concepts related to grammar: morphology that studies the formation of words, their structure and relationships between them, and syntax that studies the structure of sentences, relations between sentence units, the internal structure of phrases, and relations between them that gives meaning to sentences (Saxton, 2010). Language learners tend to claim that studying grammar is complicated and affects their ability to master a language. Therefore, integrating the grammar discussion in all language proficiencies is 
highly needed. A good understanding of grammar can help English learners to communicate actively both in oral or written form (Iksan \& Dirham, 2018).

Grammar is partly the study of what forms (or structures) are possible in a language. Traditionally, grammar has been concerned almost exclusively with analysis at the level of a sentence. Thus a grammar is a description of rules that govern how a language's sentences are formed. Grammar communicates meanings of a very precise kind. There are seven arguments for putting grammar in the foreground in second and foreign language teaching namely the sentence-machine argument, the fine-tuning argument, the fossilization argument, the advance-organizer argument, the discrete item argument, the rule of law argument, the learner expectation argument, the knowledge how argument, the communication argument, the acquisition argument, the natural order argument, the lexical chunk argument, and the learner expectation argument.

Vocational students in Politeknik Negeri Medan also adopt the learning of English as supporting their compulsory subjects. In this case, students in Computer Engineering are expected to be able to communicate using English bot in oral and written form. However, still many students rarely use English except while presenting their individual or group work in English class. It was found that they felt confident due to their low vocabulary mastery and lack of grammar knowledge (Wiraldi, Jufriadi, 2020). Therefore, those students are treated with various methods in teaching grammar integrated into speaking, listening, writing, and reading.

Social media has reached users of all levels of ages including children, teens, and also adults. Facebook, Instagram, WhatsApp, Tik-Tok, Twitter, Youtube, and many others are social media frequently used. Almost every time and everywhere the users of social media take a look at their account or even post something there. It becomes a habit to check social media as it is claimed as funny and decreases boredom.

The widespread of social media in this global era actually can be a source of learning English. It cannot be refuted that many students nowadays like reading posts on social media better than reading printed academic books. Learning on social media that the students like probably can let them eager to love studying English so it can gradually help them to improve their English skills. This encouraged the researcher to optimize the use of social media as a source of studying English. One of them is by having students do grammar task-based social media posts.

Bloom published a framework for categorizing educational goals including remember, understand, apply, analyze, evaluate, create (Bloom, 1956). Computer Engineering students in Politeknik Negeri Medan are provided four semesters to learn English. Various topics of grammar have been taught integrated into language proficiencies. Therefore, the fourth-semester students are challenged to have a task on a higher level of educational goals stated by Bloom namely analyze and evaluate. At this level, learners are expected to make judgments about the value of the methods or materials presented to them. Checking and critiquing grammar are involved in evaluating error analysis.

According to Corder (1967), error analysis has two functions both theoretically and practically. The theoretical aspects of error analysis are part of the methodology of investigating the language learning process. To know the nature of this psychological 
process, we must have the means of describing the learner's knowledge of the target language at any particular point in his or her learning career to relate this knowledge to the teaching that has been received. The practical aspect serves to guide the corrective action we must take to correct an unsatisfactory situation for the student or teacher. Thus, error analysis is expected to provide useful contributions in the field of research or even the teaching and learning process.

Troike (2006) states that EA is the first approach to SLA studies that includes an internal focus on learners' creative abilities to build language. Gass \& Selinker (2008) define error analysis as a type of linguistic analysis that focuses on the mistakes made by learners. In error analysis, a comparison is made between the mistakes made by a learner in producing the TL form and the TL itself. There are five types of errors that often appear in students' writing which are categorized by Dulay et al. (1982) and James (1998) which are included in the taxonomic surface structure, namely Omission, Addition, Misformation, Misordering, and Blends.

This study is aimed to investigate how and what the students' analyses toward grammatical errors on social media posts are. This will be beneficial as a consideration to educational practitioners in integrating grammar in teaching English and encourage students to avoid grammatical errors while writing and speaking English.

\section{METHODS}

This study was undertaken in descriptive qualitative research. The subjects of research are 15 students majoring in Computer Engineering in Politeknik Negeri Medan. The data was obtained from the assignments submitted by students dealing with the grammatical errors on social media posts. In descriptive qualitative analysis, the data concerned appear in words rather than in numbers. They may have been collected in a variety of ways (observation, interviews, extracts from documents, tape recording), and are usually "processed" somewhat before they are ready for use (via dictation, typing up, editing, or transcription), but they remain words, usually organized into extended text (Miles and Huberman). Those statements showed that the data gathered in qualitative research need to be given some editing before displaying. To analyze the data obtained, the researcher will use four steps from Miles et al. (2014), they are data collection, data condensation, data display, and data conclusion.

\section{Data collection}

This step is done by instructing students to do an assignment to capture grammatical errors on social media and giving the correction for each error. Then, the assignments were submitted on SIPADI, an e-learning platform used in Politeknik Negeri Medan.

\section{Data condensation}

This step is accomplished by selecting the data from students' assignments. The researcher checked the students' work including the picture they captured and their analysis of the grammatical error and how to correct it. Only 15 assignments were further 
analyzed. Some assignments were not analyzed further as they did not meet the requirements.

\section{Data Display}

The data obtained were 20 errors transformed in a table involving students' names, the grammatical errors on social media posts captured and students' evaluation.

\section{Data Conclusion}

Based on the data displayed on tables, the conclusion is drawn by classifying the levels of students' evaluation. This classification is aimed to identify to which level the students were able to evaluate the grammatical errors or social media posts.

\section{RESULTS}

The analyses and evaluations made by students toward grammatical errors found on social media posts are described as follows:

\section{Student 1}

Social media post: : "World clean up day 2020”

Student 1 's analysis : In the caption above, we can look at a wrong sentence, "world clean up day 2020".Clean up in the text as a verb. But I think the right one is cleanup as a noun. If we look in Bahasa clean up (membersihkan) and cleanup (bersih-bersih). In my opinion, the right sentence is"world cleanup day 2020".

Student 1 was able to identify the error of using part of speeches. It needs a deep comprehension to analyze the ambiguous meaning only because of using space or not in writing. Two words similar may have different meanings. This evaluation is highly needed to show English learners that different spelling using space only brings into different understanding and meaning. This error is categorized as misformation based on surface taxonomy error theory.

\section{Student 2}

Social media post : I very like this song

Student 2's analysis : The word like is a verb. In English grammar, the word very can only be used to modify adjectives, for example very good, very lucky, very nice. While the word is used for verbs. For example, I like this song, I love you, I adore him. Although the meaning is the same, their usage is very different. So the correct sentence is "I like this song".

Student 2 was able to identify that 'like' in social media functions as a verb. Indeed, like can also function as an adjective to show similarities. Then the verb modifier suggested to be the correction is good. The topic covered by the students is the verb, adverb, adjective. This error is categorized as misordering based on surface taxonomy error theory. 


\section{Student 3}

Social media post : : Your'e Never Alone".

Student 3's analysis : The word like is a verb. In English grammar, the word very can only be used to modify adjectives, for example very good, very lucky, very nice. While the word is used for verbs. For example, I like this song, I love you, I adore him. Although the meaning is the same, their usage is very different. So the correct sentence is "I like this song".

Student 3 was able to show the use of punctuation in shortening to be in English. However, the evaluation doesn't involve the explanation that if the quotation mark is put after your in your'e, it can bring misunderstanding about possession. This error is categorized as misformation based on surface taxonomy error theory.

\section{Student 4}

Social media post : I no perfect

Student 4's analysis : This word is wrong because it doesn't exist to be "Am" It should be: I am not perfect! So ... just hate !!!

Student 4 was able to use of to be in a nominal sentence. It doesn't involve the explanation about the use of no and not which tends to use interchangeably by people without knowing the difference. 'no' shows the total, amount, or existence of an object, while not show negation of something. This error is categorized as omission based on surface taxonomy error theory.

\section{Student 5}

Social media post : Strong people don't put others down. They lift they up

Student 5's analysis : Strong people don't put others down. They lift them up

Student 5 was able to distinguish the use of pronouns as subject and object. This error is categorized as misformation based on surface taxonomy error theory.

\section{Student 6}

Social media post : : He need you

Student 6's analysis : In the simple present, sentences with a singular subject-verb must add $\mathrm{s} / \mathrm{es}$.

Student 6 was able to distinguish the singular and plural subject and the verb used in the simple present tense. This error is categorized as omission based on surface taxonomy error theory.

\section{Student 7}

Social media post $\quad$ : I don't princess, but I am sad girls 
Student 7's analysis : What's wrong with the sentence above is, the wrong choice of words for I don't princess should be I am not a princess because the princess is a noun, not a verb. then in the sentence but I am sad girls it should be but I am sad girl without s because she shows herself as a single person, whereas if you use $s$ it shows the plural form or more than one

Student 7 was able to distinguish the use of auxiliary don't and to be in a verbal and nominal sentence. But, the evaluation doesn't cover the use of the article to avoid misunderstanding showing feeling sad or being a sad girl. The use of article a is needed in I am sad girl becomes I am a sad girl. The errors found based on surface taxonomy error theory are categorized as misformation of 'don't', omission of article 'a', and addition of the suffix -s in 'girls'.

\section{Student 8}

Social media post $\quad$ : you will have better taste in people when you start loving yourself. Student 8's analysis : you will have better taste in people when you start to love yourself.

Explanation :

Start + gerund $=$ if the sentence is past.

Start + to infinitive $=$ if the sentence is present/future.

In the sentence, the context is simple future tense ( S+Will+Inf ) So, START + TO INFINITIVE (Start To Love)

Student 8 was able to show the different meaning of sentences if the word start followed by a gerund and to-infinitive. This error is categorized as misformation based on surface taxonomy error theory.

\section{Student 9}

Social media post : Waited a long time

Student's analysis : From the caption above, we can see that there is a sentence that is wrongThe word "waited" should be used when an activity has been stopped (past). The sentence "waited" should be replaced by "waiting". So to improve the sentence above is "Waiting a long time"

Student 9 was able to evaluate the use of verbs based on present or past time. She didn't cover the use of participle in active and passive forms as it affects the meaning and understanding in communication. This error is categorized as misformation based on surface taxonomy error theory.

\section{Student 10}

Social media post : The books that I read was interesting

Student's analysis : Generally, "was" is used for singular objects, and "were" is used for plural objects. So, you will use "was" with I, he, she and it while you 
will use "were" with you, we, and they. There is a tip you might want to consider. Even though you are singular, you must use "were".

Student 10 was able to evaluate the use of agreement of singular and plural subjects with to be was or were. This error is categorized as misformation based on surface taxonomy error theory.

\section{Student 11}

Social media post : Don't forget to always give you're smile

Student's analysis : These mistakes are sometimes made when we are in a hurry to write. Your is a possessive pronoun that indicates ownership. Whereas You're is short for you are. Which is a contraction. Contraction is a word or phrase that is shortened by removing one or more letters in it. In writing, single quotes are used to indicate an omitted character

Student 11 was able to evaluate the use of contraction and she covers the use of pronoun as subject and possessive pronoun. This error is categorized as misformation based on surface taxonomy error theory.

\section{Student 12}

Social media post : It is difficultier to defend something that is allready there than to fight something that is not there.

Student's analysis : The caption on the Facebook post above has an error in the word. namely the words "difficultier" and "allready". Comparative Degree states that the properties or description of an object are more than other things. For adjectives that are long or more than one syllable, such as difficult, the formula is as follows: more + adjective. So the correct sentence is "more difficult" not "difficultier"

Student 12 was able to evaluate the use of comparative degree, but unfortunately, there is no explanation why the word 'allready' is considered as an error. The correct one is already, the addition of the letter l makes the word ambiguous even meaningless. Based on surface taxonomy error theory, the errors analyzed by students are misformation of comparison and addition of 'l' in the word allready.

\section{Student 13}

Social media post : My begs is stole yesterday.

Student's analysis : In the sentence above, there is an error in using the singular noun form (singular noun). In the sentence above using the noun Begs the sentence must use a single noun. should be: My bag was stolen yesterday

Student 13 was able to evaluate the use of singular and plural nouns, but not taking of misspelling of the bag becomes beg into account which changes the meaning. The errors 
found are categorized as misformation in spelling beg and addition of the suffix $-\mathrm{s}$ in the word begs based on surface taxonomy error theory.

\section{Student 14}

Social media post $\quad$ : Its is not just only for life, but also a forest as a lung for earth

Student's analysis : Its : singular (singular) and plural (plural). These two objects are used to distinguish the amount of an object. Usually, a plural noun is added -s to signify more than one. It should be "it".

Just only: Just is most commonly used as an adverb together with the present perfect tense. In this context, just means a short time ago, and is positioned between the auxiliary verb (had/ have/has) and the past participle. Anytime you can use 'only', you can usually use 'just' to mean the same thing. But you've got to remember that the range of uses and meanings for 'just' are quite wide.

Correction: it is not only for life but also a forest as a lung for the earth

Student 14 was able to evaluate the use of pronouns as subject and possession. This error is categorized as misformation based on surface taxonomy error theory.

\section{Student 15}

Social media post $\quad$ : Kulfi I like you ... I from Indonesian.

Student's analysis : "I from Indonesian" should be used to be 'am' and change 'Indonesian' to 'Indonesia' because 'Indonesian' is language and the meaning of the sentence is to explain that she is from Indonesia. The right sentence is " I am from Indonesia" or "I come from Indonesia".

Student 15 was able to distinguish when to use to be in a sentence, which means this student was able to define nominal and verbal sentences. This error is categorized as an omission of to be. Besides, this student also analyzes the difference between showing country and nationality. This error is categorized as the addition of the letter '- $n$ ' in the word Indonesian based on surface taxonomy error theory.

Based on the previous description, the data can be displayed as follows:

Table 1. Students' Analyses Types of Errors

\begin{tabular}{|c|c|c|c|c|c|}
\hline \multirow{2}{*}{$\begin{array}{l}\text { Subject of } \\
\text { Research }\end{array}$} & \multicolumn{5}{|c|}{ Surface Taxonomy } \\
\hline & Omission & Addition & Misformation & Misordering & Blends \\
\hline Student 1 & & & $\sqrt{ }$ & & \\
\hline Student 2 & & & & $\sqrt{ }$ & \\
\hline Student 3 & & & $\sqrt{ }$ & & \\
\hline Student 4 & $\sqrt{ }$ & & & & \\
\hline Student 5 & & & $\sqrt{ }$ & & \\
\hline
\end{tabular}




\begin{tabular}{|c|c|c|c|c|c|}
\hline Student 6 & $\sqrt{ }$ & & & & \\
\hline Student 7 & $\sqrt{ }$ & $\sqrt{ }$ & $\sqrt{ }$ & & \\
\hline Student 8 & & & $\sqrt{ }$ & & \\
\hline Student 9 & & & $\sqrt{ }$ & & \\
\hline Student 10 & & & $\sqrt{ }$ & & \\
\hline Student 11 & & & $\sqrt{ }$ & & \\
\hline Student 12 & & $\sqrt{ }$ & $\sqrt{ }$ & & \\
\hline Student 13 & & $\sqrt{ }$ & $\sqrt{ }$ & & \\
\hline Student 14 & & & $\sqrt{ }$ & & \\
\hline Student 15 & $\sqrt{ }$ & $\sqrt{ }$ & & & \\
\hline Total & 4 & 4 & 11 & 1 & 0 \\
\hline Percentage & $20 \%$ & $20 \%$ & $55 \%$ & $5 \%$ & $0 \%$ \\
\hline
\end{tabular}

Based on the table above, of 15 students, there were 20 errors found, analyzed, and evaluated by students on social media posts. It can be seen that the errors are $20 \%$ omission, $20 \%$ addition, $55 \%$ misinformation, $5 \%$ misordering, and $0 \%$ blends.

\section{DISCUSSION}

This study focuses on reading skills integrated into the grammar in which students were assigned to read social media posts, found grammatical errors then analyzed and evaluated the errors. It is different from some previous relevant studies. Kirkgöz (2010) investigated writing errors in students' written texts in Turkey using the taxonomy error theory. In conclusion, 220 cases of interlingual error were found that dominated the types of writing errors of students. Supit (2016) conducted research entitled "Error Analysis of English in Status and Chatting in the Social Media BBM", which attempted to identify, classify, analyze and describe the kinds of errors in the use of Social Media BBM. The result of this research shows that there are 16 kinds of errors made by BBM users, are the omission of the subject, omission of a verb (to be), omission of the ending for plural nouns, omission of a preposition, omission of auxiliary verb (to be, to do and to have) and omission of an article. Errors of misinformation are misinformation of singular nouns, misinformation of plural nouns, misinformation of subject, misinformation of object, misinformation of preposition, misinformation of verb, and misinformation of word spelling. Errors of misordering are misordering of an object, misordering of adverb of place, and misordering of adverb of time.

Another study by Simatupang \& Galingling (2012) investigated the errors found in job advertisements from Kompas newspapers and the fallacious trends. The methodology used in this paper was descriptive qualitative. Data were gathered randomly from job advertisements from Kompas in 2008. The data were analyzed through the following steps: first, the data were gathered and classified into errors from L1 interference, and errors from lack of grammatical knowledge. After the causes of errors were explained, then the fallacious trends were described. Data showed the inconsistency of translating Job's titles 
because of L1 interference. Errors due to lack of grammatical knowledge were classified into four categories of omission, addition, and substitution. From 44 data of omission and addition, the inflection (endings and -ed) mostly occurred. There were 24 cases found from the errors of substitution regarding the class words, prepositions, and agreement. Fallacious trends that Job's ads written in English that were free from errors proved to be contrary to the fact. The previous studies conducted are different from this study in which students were assigned to read and find the grammatical errors on social media posts and evaluated the errors by showing the correction for each error found. Then, the researcher reanalyzed the students' findings to which extent they were able to make the evaluation. It is found that of 15 students, there were 20 errors analyzed and evaluated by students on social media posts. It can be seen that the errors are $20 \%$ omission, $20 \%$ addition, $55 \%$ misinformation, $5 \%$ misordering, and $0 \%$ blends.

\section{DISCUSSION}

This study showed that students in Politeknik Negeri Medan majoring in computer engineering based on surface taxonomy theory were dominantly on misformation analysis, followed by omission, addition, misordering analysis. Misformation is the highest rate of errors found as it covers many grammar topics in English such as tenses, participle, verbal sentence, nominal sentence, part of speech, and others as analyzed by students on social media posts. Besides, no students found blends, it might due to their lack of knowledge of blends themselves. Practitioners in education are expected to take the findings of this study into account in terms of designing English teaching and learning, especially in the vocational field which relates to students' ability to analyze and evaluate grammatical errors on social media posts. Further research is also recommended to extend the discussion on other education levels, different language proficiencies, or various authentic assignments.

\section{ACKNOWLEDGMENT}

The researcher would like to appreciate the head of Politeknik Negeri Medan, English team teaching and students majoring in Computer Engineering who support the accomplishment of this study.

\section{REFERENCES}

Bloom, B. S. (1956). Taxonomy of Educational Objectives, Handbook 1: The Cognitive Domain. David McKay Company, Inc.

Corder, S. P. (1967). The significance of learner's errors. International Review of Applied Linguistics, 5(4), 161-170.

Dulay, H., Burt, M., \& Krashen, S. (1982). Heidi C Dulay - Language two.pdf. Oxford University Press. 
Gass, S. M., \& Selinker, L. (2008). Second Language Acquisition: An Introductory Course. Routledge Taylor and Francis Group.

Gleason, J. B. \& Ratner, N. B. (2016). The Development of Language, 9th edition. Allyn and Bacon.

Iksan, M., \& Dirham, D. (2018). The Influence of the Economic Students' Motivations and Language Learning Strategies towards Their English Achievement in STIE Muhammadiyah Palopo. Ethical Lingua: Journal of Language Teaching and Literature, 5(1), 110-121. https://doi.org/10.30605/ethicallingua.v5i1.737

Iksan, M., \& Duriani. (2015). A Survey of Students' Language Learning Strategies and Their English Learning Achievement in SMA Negeri 1 Palopo. IDEAS: Journal on English Language Teaching and Learning, Linguistics and Literature, 3(2), 12-27. https://doi.org/10.24256/ideas.v3i2.146

James, C. (1998). Errors in Language Learning and Use: Exploring Error Analysis. Routledge.

Kirkgöz, Y. (2010). An analysis of written errors of Turkish adult learners of English. Procedia - Social and Behavioral Sciences, 2(2), 4352-4358. https://doi.org/10.1016/j.sbspro.2010.03.692

Miles, M. B., Huberman, A. M., \& Saldana, J. (2014). Qualitative data analysis: A methods sourcebook (3rd Edition). Sage Publication Inc.

Saxton, M. (2010). Child Language: Acquisition and Development. Sage Publication Ltd.

Simatupang, M. S., \& Galingling, Y. (2012). Errors In English Ads And Fallacious Trends Of Job Advertisements In Jakarta. Lingua Cultura, 6(1), 1. https://doi.org/10.21512/lc.v6i1.389

Supit, R. (2016). Analisis Kesalahan Bahasa Inggris dalam Status dan Obrolan di Media Sosial BBM. Urnal Elektronik Fakultas Sastra Universitas Sam Ratulangi, 4(3).

Thornbury, S. (1999). How to Teach Grammar. Pearson Education Limited.

Troike, M. S. (2006). Introducing Second Language Acquisition. Cambridge University Press.

Wiraldi, Jufriadi, M. I. (2020). Improving Vocabulary Mastery Of The Seventh Year Students Using Scattergories Game In SMP Negeri 8 Palopo. FOSTER: Journal of English Language Teaching, 1(2), 159-167. 